\title{
O professor na trajetória do aluno como referência ou cicatriz: entrevista com Diógenes de Castro
}

Entrevista por Leticia Oliver Fernandes e Marina de Almeida Spinola

Transcrição por Leticia Oliver Fernandes, Matheus de Paula Silva e Pedro José de Carvalho Neto

Revisão por Gabriel Yukio Shinoda Oliveira, Gabriele Maria Oliveira, Leticia Oliver Fernandes, Marina de Almeida Spinola, Matheus de Paula Silva e Pedro José de Carvalho Neto

DOI: 10.11606/issn.2318-8855.v9i2p153-181 


\section{entrevista|}

Diógenes de Castro

Morador da Zona Leste e torcedor convicto do Santos, Diógenes de Castro entrou no curso de História da USP em 2006. Não cresceu incólume à influência de uma família de professores e, desde antes de formar-se, viveu experiências múltiplas na educação: passou por cursinhos comunitários, pela rede estadual e pela rede municipal, onde dá aulas hoje.

Os leitores e leitoras logo perceberão que sua entrevista é bem como uma conversa - não apenas pelo tom coloquial, mas pela sinceridade e abertura com que respondeu às nossas perguntas. Que não confundam, no entanto, leveza com romantização: Diógenes não tem medo de trazer uma perspectiva crítica a respeito de sua experiência como aluno de graduação na USP, das questões de saúde mental relacionadas à pós graduação e nem de sua trajetória como professor de História. Colocadas as contradições - estas que se aprofundam em um período de pandemia - dá boasvindas aos futuros educadores e educadoras e faz um convite ao trabalho no ensino público.

Boa leitura a todas e todos!

Revista Epígrafe: O que te levou a fazer o curso de História? Você já tinha alguma atuação profissional em mente, você já queria ser professor?

Diógenes de Castro: Quando a gente é adolescente, a gente quer ser tudo [risos]. Eu já quis ser juiz, já quis ser muita coisa assim, mas quando a gente vai chegando na fase final da adolescência e começa a ver o drama, a gente tem dimensão.

Meus pais são professores, tenho tios professores. Eu vivo em torno da educação desde que o mundo é mundo. Mas meus pais são de exatas. Eles são professores de Matemática. Eu cheguei a estudar por alguns anos na escola em que meu pai trabalhava. Acho que isso é importante, sempre fui da rede pública. Só por um ano e 


\section{entrevista}

O professor na trajetória do aluno como referência ou cicatriz

meio eu fiz escola particular por umas situações de briga na escola, então acabei indo para a escola particular. Mas sempre fui aluno de rede pública.

Sou formado na COHAB II [Conjunto Habitacional José Bonifácio], em Itaquera, nascido e criado lá. No Ensino Médio, eu passei no CEFET-SP [Centro Federal de Educação Tecnológica/São Paulo], hoje [Instituto] Federal, e passei a frequentar a Armênia. Na Federal, a gente ficou lá os três anos. Fiz o [Ensino] médio e [Ensino] técnico lá, mas vi que não era para mim. Eu fiz mecatrônica; eu gostava de estudar, mas não gostaria de trabalhar com aquilo, ali eu já percebi que não era para mim. Eu gosto de gente, eu gosto de me mexer, ali eu não me via no escritório, num lugar quieto, de jeito nenhum. Foi nessas que acabei... com a ideia de prestar Psicologia no final do terceiro, porque era sobre lidar com gente. Mas aos poucos eu fui percebendo que o que eu queria mesmo era ser professor.

Aí fui fazer o cursinho, eu tinha clareza do que eu queria, mas não tinha certeza se eu queria encarar. Durante o cursinho, no começo, eu já vi que eu gostava de História e decidi fazer História de vez, trabalhar com isso. Fui lá, prestei História, passei, fiz na USP [Universidade de São Paulo]. Desde o começo eu sabia que queria trabalhar na rede pública, não estava muito a fim de trabalhar em particular não.

Revista Epígrafe: Como foi quando você entrou na graduação?

Diógenes de Castro: Bom, eu morava com meus pais, em Itaquera. E tinha esse desafio de ir até a USP. Eu já estava acostumado com essas ligações, ir até a Armênia... Assim, ainda dei a sorte. Nossa... Tem o trem da [linha] coral CPTM, eu não morava tão longe da estação Dom Bosco. Morava a o quê? Uns 10 minutos a pé. Então eu pegaria ali o trem e iria para a escola. Só que obviamente eu dei o azar de ter mudança, estavam mexendo alguma coisa nos trilhos. Fechou a estação, ficou por 


\section{entrevista}

Diógenes de Castro

uns dois anos reformando. Aí eu tinha que pegar ônibus para chegar até o metrô Itaquera, do metrô Itaquera até a Sé, da Sé até a Armênia, e ir a pé uns dez, quinze minutos e voltava. Quando foi no final do Ensino Médio, liberou o trem. Da hora, estou bem.

E para a faculdade, foi a mesma coisa... Primeiro que assim, eu não tinha nem noção de como chegar na USP. A primeira vez que eu fui, eu fui pegar o busão, peguei aquele busão que ia atravessando pela avenida Europa... Nossa, e eu não esqueço, gente. A minha rua era de terra na época, só asfaltou quando eu estava no segundo ano da faculdade. Era bizarro porque, imagina... eu saindo todo lá "paquitão" de Itaquera, vou lá, pego o trem, desço na República... Eu chego lá [na Avenida Europa], eu começo a olhar Maserati, Ferrari... Quando eu entrei na USP era 2006. Eu olhei e fiquei assim: "Gente, como assim? Tem Ferrari? Não sabia". Não tinha dimensão da riqueza, nem da minha pobreza.

Para mim, foi o maior choque aquele negócio, eu comecei a ter noção de quanto eu era pobre. Essa migração [de casa para a USP e vice-versa] foi um negócio louco, eu não aguentei muito tempo, não. Eu lembro que eu gastava, entre ida e volta, quatro horas. E na faculdade eu ficava três horas e meia. Então era impossível, eu fui morar em república por conta disso. Na primeira em que eu morei, era o único cortiço que existia em Pinheiros, eu acho. A casa era bizarra, sabe aquelas casas antigas? Se pá aquilo tinha uns cem anos. E o aluguel era muito barato. Então, para mim, foi o que dava. E era bom porque eu trabalhava, eu cheguei a estagiar lá no Palácio do Bandeirantes, e, querendo ou não, ali dava para chegar a pé na [Avenida] Rebouças, para pegar ponto de ônibus e ir para lá. Não tinha o metrô, inaugurou o metrô logo quando eu saí daí, outro ódio que eu tenho no coração, pelo amor de Deus [risos]. O metrô faz muita diferença. Tinha vezes que chovia, eu demorava quatro horas, fim de faculdade... Tinha professor que ficava segurando lista até dez e 


\section{entrevista}

O professor na trajetória do aluno como referência ou cicatriz pouco da noite, eu podia não conseguir pegar o trem para voltar para casa, tá ligado? Já chegou no ponto de eu chegar na Luz e o último trem já ter saído, e eu ter que ir correndo pegar o último metrô, eu chegava em casa era quase duas da manhã. Quando acabou a estação, só melhorou porque tinha certeza do tempo que você ia demorar, não ficava preso nos trânsitos que tinha ali na Rebouças com a [Avenida Brigadeiro] Faria Lima.

Revista Epígrafe: Como era a composição social do curso de História naquela época? Você acha que está muito diferente do que está hoje?

Diógenes de Castro: A minha última experiência foi no PIBID [Programa Institucional de Bolsas de Iniciação à Docência], em 2014, que eu acabei frequentando um pouco mais o prédio, e aí reparei que deu uma mudada. Primeiro que, assim, reparei que os movimentos se consolidaram de vez, o movimento negro no Departamento de História, por exemplo, por mais que sempre tenha se feito presente, eu tive a impressão de que as pessoas estão um pouco mais atuantes, tem um pessoal do rolê mais afrocentrado, de ficar entre os seus, dá para reparar. Mesmo o movimento feminista, era um negócio muito no começo quando eu estava na graduação. De se estruturar, de ter a força que tem hoje, e mesmo assim, eu reparei de certa forma que tinha mais, vamos dizer assim, pessoas de cor em relação ao tempo que eu estudei lá.

Do vestibular que eu ingressei, de 2006 para o de 2007, mudou muita coisa. Eu entrei, fiz o último vestibular em que na segunda fase só tinha Ciências Humanas -Português, História e Geografia. Aí depois começou a cair todas as disciplinas. Quando começou a cair tudo, colou um pessoal que tinha muito mais grana. Dava para perceber. Era gente que levantava a tampa do carro do som, com DVD, que 


\section{entrevista|}

Diógenes de Castro

naquela época era 2007-2008. E não era um carro velho, era um carrinho de dois aninhos de uso no máximo ali. Então, assim, era uma galera que tinha mais grana, que ficava lá... Jogando truco, a galera do truco, que a gente tinha preconceito com os caras [risos]. Ah... é isso. Você tinha uma galera que era mais boy. Agora, minha impressão é que... é difícil você ter certeza de que grupo social as pessoas são de fato. A USP, a História, a galera que é trabalhadora mesmo, está no noturno, é uma galera que na verdade você não vê frequentar o prédio, porque elas têm que ir para casa para no outro dia trabalhar. Elas não frequentam a faculdade, elas passam pela faculdade, não sei se essa galera continua só passando pela faculdade e não usufruindo do espaço, de tudo que ele possibilita. Mas antes era uma coisa que era muito marcada, assim, o trabalhador ficava muito à parte, porque eram espaços das pessoas que no final realmente podiam acabar ficando.

Eu fiz matéria com o José Sérgio [Fonseca de Carvalho]. Maravilhoso o curso dele. Meu, depois que eu comecei a fazer as matérias de educação, ferrou, porque eu só queria fazer isso. Para terminar a licenciatura, foi muito rápido, porque eu abria matéria com professor interessante e fazia, no final eu esperava e ia fazendo. E a princípio você ia ter um tempo de limite, então eu fui pegando assim, aí quando liberaram, eu disse: "Vou fazer matérias com os professores da hora”. Eu fui pegando, e fui fazendo um curso muito bom na Educação, assim, os professores que eu escolhi lá são professores que eu escolhi a dedo. Eu acho que isso acaba sendo muito central, você escolhe um professor que tem um curso que te interessa. E a Educação é isso que vocês falaram, você pega um professor... uma disciplina horrível, meu, parece que o curso não acaba [risos]. Por isso fica a USP inteira lá, está gente de tudo que é lado, matéria. Mas assim, a licenciatura para mim foi até de certa forma a salvação, foi quando eu comecei a entrar em angústia com o bacharel. Eu terminei as matérias da licenciatura, só que eu não podia tirar o diploma da licenciatura sem tirar o bacharel. 


\section{entrevista}

O professor na trajetória do aluno como referência ou cicatriz

E para terminar o curso de História? Não aguentava, nossa! Assim, a gente estava no meio de ocupações de reitoria, a gente era uma galera que era a maior porradaria. Então não tinha muita paciência assim [risos]. Mas no final eu precisava me formar, porque eu queria trabalhar com educação e não queria ficar lá, então eu me formei depois de muito tempo. Demorei...

Revista Epígrafe: E como eram os estágios da licenciatura? Eram aceitos estágios em qualquer escola ou eram escolas específicas?

Diógenes de Castro: Não. Tinha alguns professores que até pediam para você ir em algumas escolas específicas... O que a gente tinha era: acho que eram cem, duzentas horas de estágio, não era isso? Mas eram muitas, muitas mesmo... E assim, o estágio é sempre o drama. Porque a USP sempre exigiu que se fizesse em escola pública, não sei como é hoje, aceita particular?

Revista Epígrafe: Tem professores que aceitam.

Diógenes de Castro: Ah, é? Hum... De certa forma é bom, porque... Eu acho bom e ruim. Isso foi uma coisa que eu vi muito na minha galera, na galera com quem eu andava -- a galera que se formou e que veio de escolas particulares durante sua formação, hoje eu acho que todos eles estão atuando na educação particular. Agora, aqueles que vieram de escola pública foram para a escola pública. É uma coisa que na época a gente até conversou, falou: "Estranho, né?". Eu acho que envolve um pouco você estar acostumado com aquele ambiente e se sentir parte daquele ambiente. $E$ quando a USP te obriga a ir numa escola pública, ela faz com que você comece a ver como é que é o ambiente de escola pública. A galera que vem de particular não tem 


\section{entrevista|}

Diógenes de Castro

dimensão do que é. O pessoal fala muito, comenta muito, mas não tem dimensão dos processos qualitativos que rolam dentro da escola pública. Apesar de seus milhares e milhares de problemas, como toda escola tem, de qualquer rede.

Se bem que, infelizmente, estágio é uma coisa difícil, vocês estão passando na graduação, então vocês sabem, você tem colegas que não querem ver alguém vendo a sua aula... Querem assinar para você ir embora. Eu, quando recebo gente estagiando, fico muito feliz! Pergunto como está minha aula... Nossa, eu exploro, eu pergunto: "Está bom? Está ruim? O que você achou?". Porque eu acho que a gente aprende muito no estágio. Só que tem um problema no estágio, é que ele não faz parte da nossa grade horária. Então assim, eles querem que você faça estágio, só que às vezes você está trabalhando. E você tem que se virar para matar, tem que se matar para conseguir adequar o seu trabalho ao estágio. É isso que faz com que vários alunos, também, procurem algum colega que conhece um professor que assina estágio. A graduação tem que garantir o horário que você vai guardar a aula para fazer estágio. Porque senão, eu não sei quanto a vocês, o que vocês pensam, mas para mim é inconcebível do jeito que é, que você vá no contraturno. Pô, eu trabalhava, eu dava aula em curso comunitário e depois eu passei a ser professor de estadual, categoria O. E aí? Eu tinha que trabalhar, eu tinha que fazer as matérias e adequar meus estágios, muitas vezes isso é impossível. É impossível de dar conta. E aí a galera burlava, assim, não sei como é hoje... É uma tristeza, porque o estágio é espaço de aprendizagem, tem uma potencialidade de aprender, da mesma forma como as matérias, se você vai numa escola da hora, que tem um trabalho interessante, você aprende horrores.

Sobre alunos que fazem estágio remunerado e pedem para professores assinarem. É um problema que assim, envolve um pouco a metodologia... A gente falando de educação aqui... Mas a USP não tem preocupação com os seus alunos 


\section{entrevista}

O professor na trajetória do aluno como referência ou cicatriz quanto ao método de ensino deles e de garantia de estágio. Eu estava conversando com a minha orientadora de mestrado, ela coordenou os estágios da UNIFESP [Universidade Federal de São Paulo], do PIBID, inclusive. Eles têm um trabalho muito sério de tentar garantir, de fazer parceria com a escola diretamente. Eles têm uma preocupação de como até isso tem impacto na aprendizagem dos alunos para ser professor.

Revista Epígrafe: Só um parênteses. Tem um projeto que é relativamente recente na USP, que chama Escolas Campo. É muito bom, tem algumas escolas conveniadas, inclusive acho que também tem uma conversa com a direção, com os professores, de ter um projeto. Esse aluno é acompanhado por educadoras, que são funcionárias da Faculdade de Educação, ao mesmo tempo em que ele é acompanhado por esses professores dessas escolas. Mas são pouquíssimas escolas, eles recebem pouquíssimos alunos [da licenciatura], porque eles não conseguem atender a demanda de todo mundo da licenciatura. Mas é sem receber, também. É para cumprir os horários da licenciatura.

Diógenes de Castro: Olha, uma coisa que eu acho muito difícil na USP é isso. Essas discussões de permanência aí são complicadas. Esse é também outro vespeiro. Por exemplo, quer garantir que você faça um estágio que seja em um outro horário que não seja o das aulas ou de seu trabalho. Mas também não se garante o mínimo de remuneração ou cobertura de parte dos gastos que você vai ter no dia a dia para fazer esse estágio. É um grande desestímulo, praticamente pedem para burlar. Porque olha, tem muito professor que tem vergonha mesmo, de se mostrar, ser observado. Na prefeitura, por exemplo... É minha condição hoje, eu sou professor módulo. Módulo é o professor que substitui em caso de falta ou acompanha o 


\section{entrevista}

Diógenes de Castro

professor regente que atua com os alunos, que é o responsável por dar a disciplina. E aí assim, dependendo do regente... Quando eu fui regente, várias vezes, com os módulos, gostava de dar aula junto e tal, depois a gente trocava ideia. Só que não dava para a gente fazer aquele aprofundamento por uma questão de horário. Mas a gente tentava fazer. Tem professor que não dá tanta abertura, que até fala: “Não, vai para lá, pode deixar aqui que eu cuido". E fecha a porta e não quer você lá, entende? Professor não quer ser avaliado. É muita insegurança. A gente é condenado o tempo todo, aí o cara já não quer se expor, fica com medo de ser mal avaliado. Envolve as inseguranças de sempre. E quando você tem uma estrutura em que o estágio não considera que o aluno vai entrar, vai encarar esse negócio, ele é convidado a burlar.

Revista Epígrafe: Como as experiências da graduação influenciam seu trabalho atualmente?

Diógenes de Castro: Eu comecei a dar aula no terceiro ano em um cursinho popular na [Favela] da São Remo. E assim, quando a gente começa a se descobrir como educador, a gente pega essas coisas boas e, ao mesmo tempo, vamos dando com a cara. Eu não consigo performar, por mais que a sala de aula envolva atuar, fazer uma cena, é difícil você ser alguém que você não é. Tem gente que fala: “No sexto ano você não pode mostrar os dentes, se você entrar sorrindo eles vão montar em você". Eu sou otário, eles montam [risos]. Eu não consigo lidar com algumas experiências em sala sem sentir o mínimo de empatia, de carinho, e isso vem um pouco dos educadores que foram importantes durante a minha trajetória. Aos poucos os professores foram enegrecendo. Quando eu era aluno, você contava nos dedos de uma mão os professores negros da sua trajetória, e aos poucos você vai vendo essas pessoas ocupando esses espaços. Então de identidade, você vai pegando um pouco 


\section{entrevista}

O professor na trajetória do aluno como referência ou cicatriz

do professor que era legal, como ele fazia, como ele lidava. Eu entrei na educação querendo ser professor, tem muita gente que entra porque não conseguiu estar em outros lugares, essa pessoa vai dar uma aula sem referência, porque ela não quer estar lá.

Agora, eu queria. Aquela professora negra de Geografia que era brava, Nazaré, eu não esqueço, meu deus [risos]; o professor de História que eu tive, o Lança, o cara fazia em tópicos as aulas, na lousa. Eu sou uma pessoa que usa pouca lousa. Ao mesmo tempo, eu tive o Josberto na Federal, que eu encontrei na USP depois, quando ele estava fazendo o doutorado dele. Ele virou professor da Universidade Federal de Santa Catarina. Na Federal tinha uma pegada mais acadêmica, o Josberto passou [Eric] Hobsbawm, então era muito louco, porque era uma outra pegada de aula. Você acaba pegando, dependendo dos professores. Não sei como estão os professores na graduação hoje, mas são muitas aulas que eu olho e tenho certeza que não gostaria de dar. Tinha professor que lia texto, é um negócio que acho de um desrespeito profundo. Mas tem outros professores muito bons. Eu tenho muito respeito pela Zilda [Márcia Grícoli lokoi], que é uma professora que sempre se preocupou em movimentar; respeito muito o Maurício [Cardoso], que é um cara muito importante; Antônia Terra é uma professora muito séria e preocupada com a educação pública; na licenciatura tive várias professoras com didáticas muito práticas. Eu acho que a USP teve poucos professores preocupados com a educação, mas os que eram preocupados eram muito bons. E a [Maria Cristina Cortez] Wissenbach, professora de África, eu amo ela de paixão, ela tinha uma preocupação com educação. Então são professores que acabam te marcando positivamente. Os professores que a gente tem na nossa trajetória ou te marcam como uma boa referência, como algo que você quer ser, ou te deixam uma cicatriz de como não ser como educador. De um jeito ou de outro eles te marcam. 


\section{entrevista}

Diógenes de Castro

Revista Epígrafe: Você deu aula primeiro em uma escola estadual, e depois em uma escola municipal. Como foram as duas experiências? Como foi a experiência de dar aula primeiro em uma escola estadual e depois em uma municipal?

Diógenes de Castro: Eu comecei com cursinho comunitário, no Griot 20 de novembro. Eu só sou o educador que eu sou hoje graças ao Griot. Minha primeira experiência de escola foi entrar numa sala que tinha gente do ensino médio, gente que vinha do serviço e queria prestar uma prova, prestar uma entrevista de trabalho para um emprego melhor, e tinha, por exemplo, uma senhora de 70 anos, que malemá era alfabetizada e só queria estudar por estudar. Foi uma experiência incrível, salas menores, você criava amizades, vínculos. Nossa, foi uma experiência de educação, assim... Eu sempre sugiro dar aula em cursinhos comunitários, é pensar uma aula didática, é um grande primeiro espaço. Depois eu fui para um vínculo precário do Estado, me formei e passei em um concurso da prefeitura - na verdade eu passei duas vezes seguidas na prefeitura, mas me ferrei porque ainda faltava uma matéria na faculdade. Hoje em dia só trabalho com fundamental, mas já cheguei a ingressar de novo no Estado porque estava com saudade de dar aula no ensino médio. Trabalhei com EJA [Educação para Jovens e Adultos]. Eu já trabalhei na educação com tudo que é idade, gente, só nunca trabalhei na educação particular [risos].

O cursinho, a pegada do cursinho, não é só o aluno estar aprendendo, é também uma boa performance. É chegar lá, dar uma aula divertida, que seja didática, para que o aluno entre lá e preste atenção. Mas isso não é o central na educação, a educação envolve outros aspectos, por exemplo, saber como um aluno está. Vou dar um exemplo: a primeira escola que eu trabalhei era à tarde e os alunos tinham um perfil -- envolvia classe média, alunos de periferia; era uma escola mais central, ali na 


\section{entrevista}

O professor na trajetória do aluno como referência ou cicatriz

zona sul, perto da estação Praça da Árvore. É uma escola ótima de trabalhar, delícia, uma direção mega conservadora, mas dava para fazer mil coisas. Aí um dia eu fui substituir um professor à noite, que ia faltar. A galera estava para se formar, era a última aula. Comecei a falar com eles: "Vocês viveram momentos ótimos, vão passar para uma próxima etapa". Aí alguns começaram a chorar, comecei a trocar uma ideia com os alunos. Como era à noite, era outra coisa, o cara chega do trabalho, numa escola que é central, é meio longe da casa dele, mas é o que fica no meio do caminho. Você troca ideia com outra pessoa, que quer se empregar, mas é mãe, então é outro perfil. Quando você trabalha com o ensino médio na rede pública, você tem que ter a dimensão de que, para o aluno, sair de casa e estar na escola é importante, é o local de lazer dele.

Tive um aluno no ano passado... Meu, eu fiquei arrasado, a escola no maior silêncio, pensei: "Nossa, dispensaram as turmas". Eu cheguei lá, um aluno queridão, bagunceiro, daquele jeito, tinha sido preso roubando bike, lá em São Caetano [do Sul], para vender... Porque ele, na prática, é o filho mais velho, que bota coisa dentro de casa de vez em quando. Porque, enfim, a mãe é daquele jeito, ela é usuária, e tem um monte de irmãos, e vê a barriga apertar dentro de casa e resolve se jogar. Ele foi lá, caiu, mano... Os caras queriam pegar ele de exemplo, o moleque ficou preso junto com a galera que era maior, ele tinha um black monstro, rasparam o black... Espancaram ele uns dois, três dias lá dentro, os policiais, porque ele reagiu para o guarda municipal. E foi desesperador. E aí eu te falo, se você está no EaD você perde a relação com esse cara, e às vezes é o contato, é o olho no olho. Eu estou lidando com muitos alunos que se cortam ou que tentaram suicídio. Eu tenho uma aluna com quem eu tenho muita proximidade e ela tentou se matar. Quase conseguiu, foi só por acaso que não conseguiu, e meu, eu implorei - eu faço terapia hoje - eu implorei para o meu terapeuta para deixar fazer para ela na faixa, senão eu dava um jeito, pegava 


\section{entrevista}

Diógenes de Castro

umas aulas aí e pagava, e no final ele aceitou fazer por um preço minúsculo lá que a mãe paga. Porque ela estava querendo se matar, e um dos problemas dela é justamente a relação com a mãe dela, imagina agora ela presa dentro de casa em uma quarentena com a mãe. Sabe? Tem coisas que são inevitáveis do processo educativo, que é o quê? É você saber como ele está. Se ele está bem, se ele está estourando de ansiedade, se ele está... Às vezes até apaixonado... Uns negócios bestas, assim, mas que fazem parte da nossa trajetória e às vezes impedem que a pessoa queira aprender ou não. Ou querer se aproximar, ou querer estudar.

E eu acho que agora, tentando responder um pouco a pergunta, também a diferença do Estado para a Prefeitura, do ponto de vista dos alunos, é que essa relação com os alunos é um pouco mais próxima, as escolas não são tão grandes. A escola grande da Prefeitura tem, contando todas as turmas, às vezes... Uma escola grande [da Prefeitura] é o quê, uns oitocentos alunos, novecentos? Agora, no Estado, é normal você ter escola com dois mil alunos. Eu falo para eles: "Vocês vão sentir falta daqui”, e não sei o quê... Eu falo: “Não, deixa, no Ensino Médio acabou o amor, filho, o pessoal não vai saber quem é você não", os moleques no outro ano falam: "Poxa, bem que você falava". E eu: "Eu falei, mano". Meu, e é uma coisa que assim, é fogo, porque essa relação, às vezes, é o que acaba salvando o cara. E isso também envolve um processo de envelhecer.. Quando a gente é adolescente, nessa primeira fase da adolescência, tudo é mais intenso. É aquela coisa: “Quero abraçar! Quero beijar! Meu, tô triste, nossa, quero morrer!". Então é assim... E aos poucos a gente vai dosando, a gente perde um pouco o encanto das coisas. Vai ficando mais velho, e aí é outra pegada. Mas, ao mesmo tempo, também, os alunos são mais maduros. Então, assim, tem ações dos alunos que me deixam muito tocado, do [Ensino] Fundamental.

Quando eu cheguei, imagina, tinha acabado de trabalhar em cursinho. A primeira vez em que eu trabalhei no Estado com o Fundamental, eu estranhei demais! 


\section{entrevista}

O professor na trajetória do aluno como referência ou cicatriz

Foi a primeira vez em que eu trabalhei no Fundamental. Eu acho que, entre a Prefeitura e o Estado, a grande diferença é que, no Estado, dificilmente você vai trabalhar com Fundamental hoje em dia. E na Prefeitura, o Fundamental é o carro chefe. Da Prefeitura, são nove escolas de Ensino Médio, só. E isso é uma coisa que é uma diferença muito grande, você tem mais contato com o aluno, e os alunos são... Eles acabam fazendo mais parte do processo com você. Você é educador deles, você está preocupado com o processo educativo, se ele está ouvindo, se ele aprende a dialogar, aprende a debater, aprende a ter certas posturas de como retrucar, sabe? Fazer parte do processo educativo, de saber como formar uma resolução dialógica de conflito, por exemplo. Coisas que já teve vez que eu chamei o responsável - e olha, é raro eu chamar responsável de alguém -, mas teve vez que eu já chamei responsável e, meu, eu olhava para o responsável, olhava para a criança e falava: "Esse moleque é uma bênção". Esse moleque, nossa, os pais, pelo amor de Deus, o que é isso... Não trata a criança como gente, como é que vai... Sabe? E isso no Estado se perde bastante por conta do número menor de aulas, por conta do formato que o Estado acaba às vezes fazendo, que é meio perverso, paga mal seus profissionais e as pessoas acabam tendo que ter dois empregos, e na hora de faltar em algum lugar vai faltar no Estado. Então você tem um descompromisso, um pouco... É um processo que vem de anos do Estado. Mas eu acho que em relação à prática é isso.

Eu prefiro a Prefeitura. Mas vocês vão ouvir de muita gente que prefere mil vezes trabalhar no Estado que na Prefeitura. O Estado tem uma autonomia de trabalho que na verdade faz parte do estar largado. O Estado é meio cada um faz o que quiser. Mas quando você pega um grupo da hora... Que nem na última escola em que eu trabalhei no Estado, [Escola Estadual] Brenno Rossi [Maestro], doeu exonerar. Doeu. Porque... Que grupo maravilhoso! Lá no Jardim da Conquista, em São Mateus. No Brenno, gente... Era um grupo incrível, então o grupo era da hora e a comunidade 


\section{entrevista|}

Diógenes de Castro

bancava a escola, isso faz uma diferença do caramba, se a comunidade se vê na escola. A escola em que eu trabalho hoje, por exemplo, em comparação com a outra da prefeitura... Ela fica em um prédio que foi fundado em 1972, o Álvares de Azevedo. Quando você fala com os pais, você fala com os pais que estudaram nessa escola. A relação com a escola é outra, sabe? O Brenno era uma escola que a comunidade brigou para ter porque não tinha escola. Porque os moleques tinham que ir até muito longe, a comunidade brigou, o Jardim da Conquista é isso. Lá foi um processo de ocupação. Então assim, as relações que a comunidade tem com os espaços é algo muito decisivo. E a Prefeitura, por exemplo, a última escola da Prefeitura em que eu trabalhei foi para um prédio novo e mudou seu público. Malandro... A relação era outra, porque os pais... Os pais não se viam com aquela referência, não eram os mesmos professores, então isso tudo envolve um pouco, tá ligado? Mas as grandes diferenças, assim... Tem gente que gosta horrores do Estado, apesar dos problemas do Estado, e tem gente que nem eu, que ama a Prefeitura, apesar dos problemas da Prefeitura. Envolve muito a escola em que você acaba entrando, essa é a verdade.

Revista Epígrafe: E sobre o processo de escolha da escola. Você escolhe de acordo com seu ranqueamento no concurso público, é isso?

Diógenes de Castro: No Estado e na Prefeitura, sim. Você vê a disponibilidade das vagas dentro das vagas que são postas lá. Tem uma diferença do Estado e da Prefeitura, que é uma coisa que eu acho absurda no Estado. O Estado, você chega lá, vamos supor... Você tem uma carga, sua carga obrigatória é de 19 aulas. Você tem que pegar 19 aulas, tem que se virar. Se você não tem as aulas e reduzir uma sala, e acontecer alguma coisa lá no processo, você ficou com 12. Você vai passar a ganhar por 12. Não importa, não importa! O ingresso é assim, dentro da lista que sai em 


\section{entrevista}

O professor na trajetória do aluno como referência ou cicatriz

Diário Oficial. A Prefeitura, a mesma coisa. Só que a Prefeitura... Eles tendem a organizar um pouco sua vida mais fácil. Então, você precisa olhar as escolas, ver o período. Isso é uma briga infernal, porque eles não publicam o período da escola, é você que tem que procurar, correr atrás, é uma briga. Nossa, uma briga de louco! Mas você tem a disponibilidade das escolas, tem a questão de você ser um professor de uma vaga definitiva ou de uma vaga precária. Isso é uma coisa importante. A vaga definitiva, na Prefeitura, quer dizer que a vaga é sua. Pode acontecer de você ficar excedente porque algum professor estava fora, que era da casa, que tem mais tempo que você - e isso é um critério da remoção interna, isso vale para o Estado e para a Prefeitura, é um professor que... Geralmente o que faz o professor somar pontos é tempo de casa e tempo de rede. Então, assim, para ingressar é o concurso, mas a partir daí é tempo de rede, não importa sua classificação. Você pode ter passado em quinto, em décimo, em milésimo, não importa. Você entrou quando? O dia em que você começou a trabalhar é o que conta. Então você tem problemas para as duas redes, na prática.

Mas o que é importante da questão do definitivo e do precário é que a vaga precária não é sua. No final do ano, você vai ter que escolher uma vaga definitiva que existir em qualquer lugar da rede. E na vaga precária você é o último a escolher. Cara, eu vi colegas meus acabarem indo para... Que nem um amigo meu que mora aqui no [Distrito] São Lucas, trabalhou comigo ano passado. Ele ingressou na Fazenda da Juta, que é relativamente perto aqui [da Zona Leste], só que a vaga era precária. Na hora da atribuição, só tinha vaga no Campo Limpo, ele foi para lá. Está saindo daqui.

Revista Epígrafe: Para o outro lado! 


\section{entrevista|}

Diógenes de Castro

Diógenes de Castro: Ahã. Ele sai daqui e vai para o Campo Limpo todo dia! la, agora estamos em EaD. Então assim, são algumas coisas que, se você não tiver o mínimo de melindre da rede, se informar minimamente, você acaba rodando, e nem todo mundo tem a paciência de explicar para as pessoas a diferença.

Revista Epígrafe: E a questão da formação também afeta isso? Se você faz cursos, isso também ajuda?

Diógenes de Castro: Sim. Isso é uma diferença da Prefeitura para o Estado. O Estado tem uma evolução? Tem. Só que é uma merreca. Aliás, eu não sei como está agora, porque parece que eles tiveram uma mudança que... Aliás, teve tiro, porrada e bomba, porque envolveu a reforma da previdência também- mas antes você tinha uma evolução pífia que dava muito pouco em 20 anos de trabalho. Quando você se aposentava, você basicamente aposentava com o salário inicial, então imagina... Minha vizinha aqui de baixo era professora do Estado, ela falou que aposentou ganhando R\$1.300,00. Imagina você ser um educador por 30 anos... Eu acho isso uma ofensa terrível. Na Prefeitura, a evolução tem dois campos. Você tem o de grau e você tem o de letra. Grosso modo, você tem uma evolução que faz parte de todo funcionário público da prefeitura e uma que é própria da educação. Toda vez que você sobe um, você aumenta 6,5\%. Antigamente, você aposentava com o salário que você tivesse chegado no final. Hoje não é mais assim, hoje é a média dos $80 \%$ dos maiores salários que você teve. Então assim... Mas você sabe que se você correr e aumentar rápido a sua evolução, você vai ter uma aposentadoria um pouco melhor. Então se formar, estudar, fazer curso, fazer pós-graduação, mestrado, doutorado, melhora. Só que, por exemplo, na Prefeitura, um mestrado vale nove pontos. Você pode fazer, ou um mestrado, ou você pode fazer seis formações de 20 horas e 


\section{entrevista}

O professor na trajetória do aluno como referência ou cicatriz

publicar dois artigos, três artigos, e você ganha a mesma pontuação. Agora eu te pergunto, o que é que vale mais, um mestrado ou... O quão trabalhoso é, qual a diferença?

A rede municipal tem muitos cursos que são bons. Olha, isso é uma coisa que me surpreendeu muito positivamente na rede municipal. Então assim, por exemplo, ano passado eu fiz um de africanidades e um outro que era sobre educação para migrantes. A nossa escola está recebendo muitos alunos venezuelanos, porque a gente tem uma casa que é envolvida com a ACNUR [Alto Comissariado das Nações Unidas para Refugiados], da ONU [Organização das Nações Unidas], que lida diretamente com pessoas em situação de refúgio. E a gente teve discussões sérias, convidou a diretora, que é uma venezuelana em situação de refúgio, para discutir como é a situação do refúgio, como é, ajuda até em relação aos registros. Mesmo a movimentação de educação assim, quando você pega uma escola da hora, mano, tem umas discussões muito boas na rede.

Revista Epígrafe: Você falou que a própria prefeitura que organiza. Como é isso? É a Secretaria [Municipal de Educação] que faz ou é a DRE [Diretoria Regional de Educação]?

Diógenes de Castro: A gente tem, na Secretaria Municipal de Educação, uma Divisão Pedagógica. Hoje se chama DIPED. A Divisão Pedagógica é ramificada em todas as Diretorias de Ensino. A Diretoria de Ensino é como se fosse espécie de subprefeitura de escolas. Eu sou, por exemplo, professor aqui do São Lucas, mas a minha Diretoria é do Ipiranga. Ela pega as escolas lá da DRE Ipiranga até lá as do São Lucas, tem umas até mais longe. E tem sua Divisão Pedagógica. Essas Divisões produzem cursos e oferecem aos professores, sem remuneração... Às vezes, nas gestões do PT [Partido 


\section{entrevista|}

Diógenes de Castro

dos Trabalhadores], tinha dispensa de ponto. Você ia lá fazer, que eram coisas que eram mais obrigatórias, por exemplo os debates do currículo. Com a gestão do PSDB [Partido da Social Democracia Brasileira], recente, isso mudou. É contraturno. Então você faz se você quiser - e entre aspas. Porque, dependendo dos horários, se o professor acumula cargo e não consegue ir... Enfim, é uma loucura.

Revista Epígrafe: E aí não tem como ascender na carreira?

Diógenes de Castro: Não tem. E os cursos, querendo ou não, por você ter que se formar para você aumentar seu salário, acabam sendo... Dá uma certa obrigatoriedade, mas ao mesmo tempo esses cursos são bacanas e são organizados pelos próprios educadores. A galera da DIPED são professores da rede que geralmente são designados pela própria prefeitura. O chefe de gabinete da Secretaria organiza uma pessoa ou outra, mas o grosso das pessoas que estão na Secretaria Municipal de Educação, os funcionários de DIPED, são pessoas que já vêm de anos na rede.

Revista Epígrafe: Queríamos saber um pouco sobre como é o cotidiano de trabalho do professor, nessa coisa mais do dia-a-dia, dentro e fora da escola. Porque a gente sabe que o trabalho do professor é quase o tempo inteiro [risos].

Diógenes de Castro: Eu acho que, assim, todo professor deveria se preocupar com a sua saúde psicológica e física, uma coisa que geralmente não rola. Eu passei a me cuidar melhor nesses aspectos com o tempo. O professor acaba vivendo intensamente a sala de aula, intensamente os problemas da escola. Se você vai em uma roda de conversa de professores geralmente o papo é aluno. Então, assim, o 


\section{entrevista}

O professor na trajetória do aluno como referência ou cicatriz

cara não sai da escola. E por um tempo eu até evitei de falar um pouco de escola dentro de casa, porque eu falava: "Não, eu preciso ter um momento em que eu não pense nisso, não trate disso", mas muitas vezes é impossível. Na verdade a gente tem que se cuidar em um aspecto geral, mas no cotidiano do professor é inevitável. Vou falar um negócio para vocês verem como fica enraizado. Eu estava fazendo academia. Na academia, eu só ouvia o álbum AmarElo, do Emicida. Ponto. Que é um álbum maravilhoso. E aí eu estava ouvindo uma música, a Ismália - na verdade o CD inteiro dá para trabalhar em sala - e pensando: "Pô, isso aí dá para fazer um trampo da hora na sala de aula, aproveito e já falo do álbum, e não sei o quê". Mano! Eu estava na academia, tentando relaxar, para cuidar um pouco do corpo... E pensando a aula. Em toda a trajetória de formação do educador, ele acaba pensando na sala de aula.

Acho que a coisa que a gente mais peca, como educadores - e isso é diferente de todos os outros movimentos. O movimento negro tem uma literatura negra muito forte; o movimento feminista também. Agora, os movimentos de educação, quantos educadores da rede pública se organizam de forma orgânica para garantir a produção do conhecimento? Que a produção do conhecimento, que é feita no dia a dia, seja organizada e divulgada? Muitas vezes o formato acadêmico não é para a gente, isso é que é cruel. O formato acadêmico é o formato acadêmico. Ele pode ajudar, mas a gente tem que procurar um pouco a nossa forma. Pô, a gente não faz essas práticas de produção de conhecimento, isso é uma coisa muito triste. E a gente produz muita coisa, a gente produz muito conhecimento no nosso dia a dia, a gente vive o processo educativo na sala de aula. Quando o pessoal vive falando que não gosta da academia e não sei o quê - porque eles têm um preconceito com a academia também, por várias razões que a gente já conversou aqui. Mas a sala de aula em si, ela é muito rica. Mas você tem que ter clareza, quando você escolhe a profissão de ser educador, ser um professor, que você vai deixar muitas e muitas e muitas horas 


\section{entrevista|}

Diógenes de Castro

do seu dia para pensar sobre o assunto, e que toda vez que você for estudar, [de] certa forma vai estar pensando no assunto, de como você vai usar isso dando aula, é muito difícil você escapar disso. Não tem como.

Revista Epígrafe: Nossas próximas questões têm mais a ver com o processo de formação. Você falou bastante sobre os cursos que são organizados pelas Diretorias de Ensino, e você também falou do papel do mestrado para a carreira. Queríamos saber um pouco mais sobre esses cursos e do seu mestrado no ProfHistória [Mestrado Profissional em Ensino de História], que você fez na UNIFESP, certo?

Diógenes de Castro: Eu fiz e não concluí. Por isso é que eu falo da questão da saúde mental. Mas eu peguei uma orientadora que era um amor. Quando eu desisti, no dia em que eu vi que não ia sair... Nossa, foi horrível para mim, mas ela mega apoiou, mega entendeu. Ela sempre fala: “Quando você estiver pronto, volta, que eu quero o seu texto. E eu vou te orientar, isso aí eu não estou negociando". Eu tive muita sorte.

Mas dá para falar do ProfHistória porque vivi todo o processo. Acho que a primeira coisa que tem que falar é assim... O problema da academia é que ela não é pensada para o trabalhador. O ProfHistória geralmente é pensado para o trabalhador. Essa é que é a grande novidade. Mas você tem diferenças dos ProfHistória. A gente descobriu que a galera da Unicamp, na época, tinha horário de aula de manhã e de tarde. Mano, o professor precisa saber que seu período de aulas vai ser o ano inteiro de manhã, não pode ficar mudando. Não tem conversa! Como assim? E isso já foi, por exemplo, uma preocupação do ProfHistória da UNIFESP. O curso, assim, eu acho que uma das coisas mais incríveis é você juntar professores. A proposta do ProfHistória, para começar, você vai fazer as disciplinas, você faz sempre junto. Você forma uma turma. A gente se tem no WhatsApp e conversa todo dia até 


\section{entrevista}

O professor na trajetória do aluno como referência ou cicatriz hoje. Gente, foi assim, e é muito louco, porque, por sermos professores, a gente praticava vivências de professor. E aí os professores das disciplinas entravam no nosso ritmo. E a gente pegou um grupo de professores muito bacanas lá. A galera da UNIFESP, eles entenderam que a gente era trabalhador e ao mesmo tempo pessoas dedicadas e preocupadas em pensar o ensino. E a maioria a galera do ensino público. Então, quando você tem um grupo bacana, o negócio deslancha. Foi um processo incrível. O mestrado me fez pensar sobre problemas, situações e questões. E como a galera toda estava junta pensando a discussão do ensino... Era uma academia mais próxima, voltada ao que se pensa sobre educação. E foi por um acaso de um grupo que bateu o santo das coisas, que tudo deu certo assim, de certa forma.

Mas geralmente os espaços de formação são gerados pela própria academia. Isso é um problema, porque não existe algo parecido com, por exemplo, o magistério, sabe? Vocês conhecem o magistério ou é coisa de idoso [risos]? Então, o magistério é o quê, no limite? É uma discussão de se formar educadores com educadores praticando. E são educadores na prática, eles estão na rede. Então, de certa forma, é um espaço de formação, de produção do conhecimento e de compartilhar experiências dos educadores com os educadores. Isso se perdeu no processo da academia, porque a academia nunca se preocupou em estar junto aos educadores. Historicamente, a academia no Brasil se formou à parte do processo educativo. Então isso nunca foi orgânico, e não vai ser agora que vai ser orgânico, misturado e junto. A gente briga por espaços para se encaixar no que sobra, e isso... Todos os processos de curso, geralmente são no formato acadêmico, e que, meu, às vezes não responde um pouco às nossas expectativas. Acho que é isso.

No ProfHistória da UNIFESP, você não entra com um projeto de pesquisa. Você passa na prova e eles vão selecionar os melhores. Você acessou porque você acessou. Não é um processo em que as afinidades acabam dominando. E quando você entra 


\section{entrevista|}

Diógenes de Castro

lá, você entra sem projeto. E esse é que é o drama: construir o projeto, pensar seu problema de pesquisa, pensar tudo, dentro de dois anos. Malandro... É muito pouco tempo, e isso foi uma das coisas... Isso dando aula!

O meu tema, como eu estava muito envolvido com a discussão do currículo, eu queria pensar... No começo, eu queria discutir os currículos da Prefeitura para pensar continuidades e descontinuidades do currículo municipal. Como foi o processo... Fazer uma análise assim. Depois, na qualificação, eu percebi que eu queria analisar os currículos da gestão do PT. Analisar as rupturas e as continuidades, e de como o currículo nacional se articulava, e fazer uma discussão curricular. E quando você tem essa perspectiva de como funciona o processo, como funciona o currículo na Prefeitura, você tem clareza. O meu tema de pesquisa não era tão aplicável à sala de aula. Teve colegas que trabalhavam, por exemplo, o rap na sala de aula. Teve outro que ia discutir África. Então, assim, tem alguns problemas que são mais próximos, e tem outros que são mais distantes, mas a discussão do mestrado - isso envolve as disciplinas, os artigos que você escreve durante a disciplina... As discussões dos textos dentro das aulas da disciplina, acho que foi o processo mais louco do mestrado. E o mestrado profissional, o ProfHistória, te dá a oportunidade de você conhecer educadores que pensam a educação e isso, sim, influencia a maneira que você dá aula. Eu sou muito grato. Eu não saí a mesma pessoa, eu tinha muito mais clareza de que eu gostava muito da educação, gostava muito de ensinar História, e do papel... E acho que a coisa que mais me deixou claro da importância do currículo é saber que eu sou... Eu já sabia, mas fica muito claro que a operação de seleção de escolhas do que eu vou ou não vou trabalhar. E eu resistir ao currículo nacional e querer fazer uma outra proposta de trabalho, que eu acredito que seja melhor para os meus educandos, eu percebi que tenho que fazer assim e pronto, desde que eu respeite as normativas e as legislações, beleza, a gente faz caber. Mas a sala de aula é do 


\section{entrevista}

O professor na trajetória do aluno como referência ou cicatriz

educador, e isso o processo de formação forneceu bastante... De ter mais segurança no que você está fazendo. E os próprios debates que eu já falei, gente, que foram incríveis.

Revista Epígrafe: Como está sendo a sua adaptação de trabalho agora, nos tempos do coronavírus? Quais são os limites do ensino à distância?

Diógenes de Castro: Eu acho que assim, deixa eu só comentar com vocês como estão sendo as decisões nesse momento [abril de 2020]. A gente em um primeiro momento entrou em recesso, os alunos... Os recessos que a gente teria no meio do ano, pontes, tudo se juntou e fez um recesso agora até se decidir o que fazer. A Secretaria de Educação, vendo que o problema é maior, e falando aos poucos também, para não gerar pânico na população, a verdade é essa. O Secretário da Educação está falando agora de dois meses em casa. A Prefeitura de São Paulo, o Estado até agora já organizou. O Estado na verdade foi o processo mais direto e reto, já tem matéria postada e tal, organizado, os professores já estão até bem melhores. A Prefeitura está uma zona, na verdade. Porque... A Prefeitura, no ano passado contratou a Microsoft para fazer o e-mail institucional nosso, que ninguém incorporou. Aí, de repente, ele vira importante, porque é onde a gente vai fazer, a gente vai fazer reuniões pelo [Microsoft] Teams. Então, a partir de agora os professores vão fazer reuniões com a gestão, e todas as reuniões pedagógicas que tiver vão ser pelo Teams. Só que, para seguir o modelo do Estado, os caras resolveram também entrar no Google For Education. Então, do nada, para começar, os professores estão tendo dois e-mails diferentes institucionais e a recomendação inicial - por enquanto, a gente vai descobrir - é que se use o Google Sala de Aula para fazer o contato com os alunos. Só que eu já usei o Google Sala de Aula com os meus alunos nessa escola em que eu 


\section{entrevista|}

Diógenes de Castro

estou agora. Eu usei porque eu via que os alunos mexiam muito no celular e tal, e eu falei: "Mano, vou fazer esses moleques aprenderem a usar esse celular para estudar". Eu adaptei algumas atividades, algumas coisas que iam com o celular, algumas atividades que acabavam sendo em grupo ou dupla porque nem todos tinham celular, aí você garantia que fizesse. Mas teve todo um momento em que eu parei, sentei do lado, ensinei a usar, fiz uma aula só para apresentar, para eles cadastrarem a sala, fiz vários baratos lá. E aí, do nada, os caras querem garantir, com alunos que não vão ter, às vezes, o acesso.

A gente está muito puto da vida, porque a gente está falando de um universo em que $40 \%$ dos alunos não têm internet em casa, computador ou telefone. Como a gente vai garantir que esse aluno vai... Aí aquele caderno impresso, que o Secretário de Educação ficou passando aí no jornal... Um caderno que, meu, desculpa, é justamente tudo o que a gente é contra na Prefeitura, porque é fazer no mesmo formato que o Estado, que é aquele caderno do aluno que instrumentaliza e tenta centralizar um currículo do que deve ser ensinado, da maneira que deve ser ensinado e dane-se se ele se adequa ou não, se tem interesse, se faz parte do aluno, se faz parte da trajetória daquela comunidade. Então assim, são umas coisas que... Do nada eles querem fazer de cima para baixo. Para quê? Para falar que teve ano letivo, para falar que teve normalidade. Não tem normalidade e não tem processo educativo com EaD desse jeito, desculpa. Não tem como, e assim, eu conversando por exemplo com a minha vizinha aqui embaixo, que agora vai começar a ter as aulas à distância, e ela estava falando, o filho dela é da Prefeitura. Ela: “Pô, mas eu estou com meu marido e meu marido está em trabalho. Às vezes eu não consigo explicar, tirar dúvida". Como vai fazer? Como você vai organizar? Ele, por acaso, tem acesso à internet aqui. E o aluno que não tiver? Como vai funcionar? Como ele vai se garantir? Todas essas perguntas não estão com respostas e isso, para a gente, é o incômodo central da 


\section{entrevista}

O professor na trajetória do aluno como referência ou cicatriz

discussão. Eu não vejo problema em usar os recursos digitais, na verdade eu apoio. Mas aí é do nada, não tem quem oriente. Eu estava trabalhando o oitavo e nono ano, que estão no final do processo educativo, imagina quem está na alfabetização! Imagina na alfabetização.

Revista Epígrafe: Por fim, gostaríamos de saber: que dicas você daria para um estudante de História que gostaria de seguir na área da educação? O que você diria para esse estudante?

Diógenes de Castro: Bom, primeiro, bem vindo, seja feliz! [Risos]. É verdade, meu. Geralmente, quando a pessoa vem para querer saber, falam: “Não venha! É uma desgraça!". Mentira, gente, não é. Meu primeiro convite é: venha para a educação pública. Gente, tem que entender assim... Eu falei mal da USP na entrevista, e isso é um pouco injusto porque boa parte do que eu sou é justamente... A USP foi o espaço que acabou me formando, hoje eu acabo tendo a profissão por conta de ter tido esse espaço e a gente sabe muito bem que, pelo formato que a USP faz, por ter grandes professores -- que às vezes são grandes pesquisadores que acabam compartilhando a pesquisa -- a gente tem a oportunidade de entrar em uma formação muito mais profunda do que vários colegas.

À pessoa que está lendo isso, seja bem vinda à área de educação! A educação é um espaço incrível. Os alunos são maravilhosos... Às vezes, a gente não vai ter as condições ideais com os nossos colegas. Cara, você não vai ter condição ideal em lugar nenhum, então desapega. Simplesmente vai. E vá para a educação pública. A gente tem um compromisso, pelo menos por um tempo, acho que a gente deveria ter um compromisso de atuar no espaço público que nos formou por alguns anos. Então, se você não pretende seguir a vida inteira porque as condições não são ideais, por $x$ 


\section{entrevista|}

Diógenes de Castro

situações, beleza, mas vá. Vá e seja um bom educador lá, eu garanto que você vai ter grandes experiências. Só não vá se enfiar em qualquer situação que você não seja obrigado.

Outra dica: faça o estágio direito, faça o estágio direito, faça o estágio direito [risos]! Se você ver que o estágio está sendo ruim, que o professor é ruim, que a escola é ruim, vai para outro lugar. Se você não está se sentindo à vontade, procura outro. Não pisca. E você vai sentir se o ambiente está legal ou não para você estagiar no primeiro dia. Você vai sentir na sala dos professores, pelo jeito que os professores falam dos alunos, conversando com o professor com quem você está fazendo estágio, pela maneira que você é acolhido pela coordenação. Então, assim, você vai saber se o espaço é feito para você ou não. Faça do estágio algo valoroso, você já é obrigado a fazer. Mas faça dele um espaço prazeroso. "Pô, não tô a fim de fazer aquelas horas". Beleza, mas faz um pouco. Você tem que ter contato! É ali que você vai ver se você quer ou não aquilo ali para você. E de certa forma é uma oportunidade para a gente saber mais até sobre nós mesmos.

Bom, deixa eu ver outra dica para quem está na graduação, coisas que eu queria que alguém me falasse a tempo... Ah! Prestem concursos de educação durante a graduação. Como todo vestibular, nós que já passamos, é técnica, é treino. Ajuda a gente também até a observar como essas coisas acabam chegando na [educação básica], durante a nossa trajetória de formação na faculdade. Então acho que vale a pena. Sem querer, você descobre alguns autores. Eu fiz... Eu prestei uma vez o concurso de professor, eu quase passei, da Prefeitura, no segundo ano. E caiu um autor que eu não conheci na graduação, eu conheci no concurso. Que é o [Marc] Ferro, nunca tinham falado do Ferro para mim. E aí eu achei muito louco, comecei pegar uns livros lá na Biblioteca Florestan [Fernandes]. Você tem espaços em que, 


\section{entrevista}

O professor na trajetória do aluno como referência ou cicatriz sem querer, você acaba conhecendo coisas muito incríveis. E isso envolve você meter a cara nos processos que tem por aí na vida.

E um último... É um pedido, de certa forma, acho que é mais um pedido. Não deixe a sua trajetória como aluno tomar a sua referência de como você vai ser como educador. Quando você muda o lado, você é outra pessoa. Você não é mais a pessoa que você era como aluno. Sua perspectiva de aluno não é a sua perspectiva de educador. Não é. E esse começo de dar aula, de você entender que você está do outro lado da mesa, é muito importante você entender que mudou. Às vezes a gente quer opinar sobre sala de aula porque a gente foi aluno. Mas a gente não está opinando, a gente está só viajando, divagando, a gente não está pensando o processo educativo! É verdade, a gente está falando das nossas lembranças, da nossa memória, o que é da hora também, porque envolve um pouco como você chegou lá. Só que isso não pode ser o central.

Eu acho que esses são os toques mais sinceros que eu poderia dar. 